\title{
Effect of Nutrient and Weed Management Practices on Yields and Economics of Aromatic Rice in Semi Arid Region of Bihar, India
}

\author{
Shashimala Kumari ${ }^{1}$, Vinay Kumar ${ }^{1 *}$, Shashidhar Yadav ${ }^{1}$, Vijay Kumar ${ }^{2}$, \\ Santosh Kumar Singh ${ }^{3}$, Rajan Kumar ${ }^{1}$ and Ravi Nandan ${ }^{1}$
}

${ }^{1}$ Department of Agronomy, Dr. Rajendra Prasad Central Agricultural University, Pusa, Samastipur, Bihar, India, ${ }^{2}$ Krishi Vigyan Kendra, Manjhi, Saran, Dr. Rajendra Prasad Central Agricultural University, Pusa, Samastipur, Bihar, India

${ }^{3}$ Department of Soil Science, Dr. Rajendra Prasad Central Agricultural University, Pusa, Samastipur, Bihar, India

*Corresponding author

Keywords

Aromatic rice,

Nutrients, Weed,

Management, Yield,

Economics

Article Info

Accepted: 05 February 2020

Available Online: 10 March 2020

\section{A B S T R A C T}

A field experiment was conducted during kharif season of 2017 at Dr. Rajendra Prasad Central Agricultural University, Pusa, Samastipur (Bihar) to investigate the "Effect of nutrient and weed management practices on yields and economics of aromatic rice ". The experiment was laid out in split-plot design and was replicated thrice. The treatments comprised three nutrient levels viz., N1= $100 \%$ RDF; N2=75\% RDF + FYM 5t/ha; N3=50 $\% \mathrm{RDF}+\mathrm{FYM} 10 \mathrm{t} / \mathrm{ha}$ in main - plot, and six weed management practices viz., W1 = Brown manuring; W2= Bispyribac- sodium @ $25 \mathrm{~g} / \mathrm{ha} \mathrm{PoE}$; W3= Chlorimuron ethyl + Metsulfuron methyl (Almix) @ $4 \mathrm{~g} / \mathrm{ha}$ at 20 DAT; W4= Pyrazosulfuron @ $25 \mathrm{~g} / \mathrm{ha}$; W5=Weed free; W6= Weedy check in sub-plot. The results revealed that treatment $\mathrm{N} 1$ recorded the maximum grain and straw yield and also B: C ratio. Among weed management practices, treatment W5 recorded the maximum yield of rice grain \& straw whereas, under weed management practices, the maximum value of net returns and $\mathrm{B}$ : $\mathrm{C}$ ratio was recorded under $\mathrm{W} 2$. However, the maximum gross return was obtained in W5. Thus, it may be concluded that the nutrient level N1 is superior to N2 and N3. Secondly, high cost involved in manual weeding makes herbicidal treatments more viable proposition. The weed management practice W2 is a most effective for transplanted aromatic rice. 


\section{Introduction}

Rice is the staple food for more than $60 \%$ of Indian population and it accounts for 42 per cent of the national food grain production and our food security system hinges ultimately on the performance of this crop. But the crop is beset with many ecological problems which hinders the sustainable crop production. In India, the area under rice cultivation is $42.9 \mathrm{M}$ ha with an annual production of 109.15 million tonnes and an average productivity of 2.54 t/ha (Anonymous, 2017) ${ }^{(2)}$.

In Bihar, rice is cultivated in around 3.21 million hectares with the production of 6.49 million tonnes and productivity of $2.019 \mathrm{t} / \mathrm{ha}$. Unfortunately, in Bihar out of the total rice growing area, $70 \%$ area is under unfavourable situation like rainfed upland (20\%), rainfed lowland (40\%) and deep water rice (10\%). Low productivity under such unfavourable agro-ecological situation has complex the state to have a low level of crop productivity. However, in view of high growth rate of population and wide spread poverty, the situation needs to be changed their mind set to turn rice into a lucrative economic production rather-than a simple food commodity and it requires a technological breakthrough to address the problem of crop production.

A major hindrance in successful cultivation of rice is heavy infestation of weed causing drastic reduction in yield. Besides chemical fertilizer, organic manure is also an important source of nutrient added to the soil but contain low amount of nutrient and therefore, whole crop requirement cannot be fulfilled by its sole application.

Chemical fertilizers are available in fixed grades. Hence, all nutrients are not supplied in balanced quantities. Cultivation of aromatic rice is very remunerative as it fetches sufficiently higher price over the course varieties, even in the local markets (Bali and uppal, 1995) $)^{(3)}$. However, aromatic rice may cause reduction in total rice production owing to low productivity of aromatic rice varieties which belong to photosensitive tall indica group, and generally even at very low doses of fertilizers. However, a concerted effort on the front of breeding higher yielding aromatic rice varieties has evolved a large number of aromatic rice varieties which have capabilities to tolerate moderate and at times moderately higher doses of fertilizers.

Attempts are being made to introduce high yielding aromatic varieties by replacing the traditional photosensitive tall indica scented varieties in the North Bihar region.

Nutrient management must be sound for achieving the production target in sustainable manner. Use of chemical fertilizer is the fastest way of counteracting the pace of nutrient mining. It promotes the growth and development of rice crop and is responsible for over 50 per cent of the crop yield increment.

Weed is one of the most important negative factors limiting the rice production, which do not only compete with crop for applied nutrients but also impair the quality of the produce. Yield reduction in transplanted rice has been reported to be $28-45 \%$ due to uncontrolled weeds (Singh et al., 2003) ${ }^{(12)}$. Besides yield reduction, weeds deplete nutrient from soil to an extent of $42.07 \mathrm{~kg}$ nitrogen, $10 \mathrm{~kg}$ phosphorus and $21.80 \mathrm{~kg}$ potassium per hectare respectively (Puniya et al., 2007) ${ }^{(8)}$. Weed management is an important component of plant protection improving the production potential of crops. Information available on nutrient and weed management under aromatic rice is not sufficient. Therefore, the aim of the study was to evaluate the effect of nutrient and weed management under aromatic rice. 
Materials and Methods

\section{Material}

\section{Study site characteristics}

A field experiment was conducted during Kharif season 2017 at research farm of the Dr. Rajendra Prasad Central Agricultural University, Pusa (Bihar). The experimental plot had uniform topography with good drainage and assured irrigation facility. The average rainfall of the area is $1276.1 \mathrm{~mm}$ out of which nearly $1026.0 \mathrm{~mm}$ is received during the monsoon season between June to September. The soil of the experimental site was sandy loam in texture with alkaline $\mathrm{pH}$, low in organic carbon and available N, P, K \& S content.

\section{Treatments and experimental design}

The experiment was laid out in split-plot design with nutrient management in main-plot and weed management in sub-plot with three replications. The treatments were randomized as par procedure given by Cochran and Cox $(1952)^{(5)}$. The treatments involved three nutrient levels viz., N1= $100 \%$ RDF; N2=75 $\% \mathrm{RDF}+\mathrm{FYM}$ 5t/ha; N3=50 \% RDF + FYM $10 \mathrm{t} / \mathrm{ha}$ in main plot, and six weed management practices viz., $\mathrm{W} 1=$ Brown manuring; $\mathrm{W} 2=$ Bispyribac- sodium @ $25 \mathrm{~g} / \mathrm{ha}$ PoE; W3= Chlorimuron ethyl + Metsulfuron methyl (Almix) @ 4 g/ha at 20 DAT; W4=Pyrazosulfuron @ $25 \mathrm{~g} / \mathrm{ha}$; W5=Weed free; $\mathrm{W} 6=$ Weedy check in sub plot.

\section{Nursery raising}

The seed was treated with fungicide SAAF (Carbendazim+Mencozeb) @ 3g/kg seed before sowing to protect the crops from seed borne diseases. Seed of rice variety Rajendra Bhagwati was raised in nursery by "Wet bed method". Seed beds of $8 \times 1.25 \mathrm{~m}$ size were prepared in dry condition. In addition $1 \mathrm{~kg}$ of nitrogen, $1 \mathrm{~kg}$ of phosphorus and $0.5 \mathrm{~kg}$ of potash were also applied @ 1000 sq. m through Urea, DAP and MOP, respectively at the time of last ploughing. Further, top dressing was done with @ $1.0 \mathrm{~kg} \mathrm{~N} / 1000 \mathrm{sq}$. $\mathrm{m}$ in the form of urea at 10 days after sowing. Need based irrigation and weeding was also done.

\section{Field preparation}

The experimental field was ploughed immediately after the harvest of previous wheat crop by a tractor drawn harrow in summer to expose weeds and the eggs of harmful insects. The field was prepared by following two cross disc harrowing and two cross tiller operations and finally the field was levelled by planking. Thereafter, the field was flooded with water and puddled by tractor. After puddling field was levelled finally.

\section{Nutrient application and sowing}

Recommended fertilizer dose of nitrogen (120 $\mathrm{kg} / \mathrm{ha})$, phosphorus $(60 \mathrm{~kg} / \mathrm{ha})$, potash (40 $\mathrm{kg} / \mathrm{ha}$ ) and FYM as per treatment was applied. Half dose of nitrogen\& potassium and full dose of phosphorus \& FYM were applied as basal dose whereas, remaining half dose of nitrogen and potassium were applied at the time of tillering.

\section{Irrigation}

Plot wise frequent irrigations were given to maintain the $5 \mathrm{~cm}$ level of standing water in early growth stages. At later stages, irrigations were given as and when required to maintain saturated soil condition.

\section{Herbicide application}

Herbicides like Bispyribac-sodium @ 25g/ha, Almix @4g/ha, Pyrazosulfuron @ 25g/ha 
were applied as post emergence at 20 DAT, in an aqueous solution using 800 litres of water.

\section{Brown manuring}

In brown manuring practice introduced where Sesbania seed @ $40 \mathrm{~kg} / \mathrm{ha}$ is broadcasted three days after rice sowing and allowed to grow for 30 days and dried by spraying 2, 4-D ethyl ester which supplies upto $35 \mathrm{~kg} \mathrm{~N} / \mathrm{ha}$ dry matter, control of broad leaf weeds.

\section{Methods}

\section{Grain and straw yield}

Net plots were harvested after removing the border rows. Grain yield was recorded after threshing, winnowing and cleaning the produce. The moisture content of the samples drawn from each plot was determined with the help of moisture meter and the yields were adjusted at 14 per cent moisture. The grain yield obtained from the net plot area was finally converted into ton per hectare (t/ha). The straw obtained after threshing the plant of net plot area was air dried and weighted. The weight of straw, thus obtained was converted into ton per hectare (t/ha).

\section{Economic analysis}

The benefit-cost ratio was calculated by considering the variable as well as fixed inputs and prevailing market rates, the expenditure incurred on various inputs and operations. Benefit cost (B: C) ratio was calculated by dividing the net return by total cost of production.

\section{Statistical analysis}

Data pertaining to various plant characters were subjected to statistical analysis by the technique of analysis of variance as described by Cochran and Cox $(1962)^{(5)}$. The significance of treatment effect was tested by "Fe test (Fisher 1958) $)^{(6)}$, standard error of differences was computed and recorded along with the summary results. Critical differences for different groups of treatments and their interactions at 5 per cent level of significance were calculated where ever F-test was significant.

\section{Results and Discussion}

\section{Grain and straw yield}

The highest grain yield was obtained in treatment N1 which was found significantly superior over N2 \& N3 Similarly, N2 significantly higher over N3. Grain yield was significantly influenced by weed control treatments. Weed management practice like weed free (W5) obtained the highest grain yield closely followed by W2 and in turn both had significantly higher grain yield than W4, $\mathrm{W} 3$ and W1. The grain yield recorded among the chemical weeding did not vary significantly among them. The reduction in grain yield in weedy check was possibly due to severe weed infestation in the crop field. The weeds grow freely and attained vigour enabling to compete with the crop plants for nutrient, moisture and sunlight throughout the growing season and thus suppressed the crop growth which hampers the fullest yield potential.

However, the reason for higher yield under weeding condition particularly under cultural treatment might be due to increased aeration through pulverization of soil which provided better crop growth condition for proper development of root and reduced the state of crop weed competition during the early stages of crop growth. The plant did not face either the nutrient or moisture deficits caused by heavy weed infestation and enjoyed weed free condition during its peak vegetative and developmental phases and had favourable soil 
moisture conditions for optimum physiological functions. The finding is in agreement with the observation of Singh et al., (2009) ${ }^{(11)}$ and Srivastava et al., (2013) $)^{(14)}$.

Straw yields varied significantly due to nutrient levels, 100\% RDF (N1), proved significantly superior over N2 \& N3 similarly, N2 significantly superior to N3. Weed management treatment i.e., W4 recorded the higher straw yield followed by $\mathrm{W} 1$ and both were found significantly superior than W5, W2, W3 and weedy check W6. The straw yields recorded under $\mathrm{W} 4$ and $\mathrm{W} 1$ were at par. Nutrient level increased the straw yield obviously by increasing the plant height, number of tillers, and dry matter accumulation (Sharma et al., 2017) ${ }^{(10)}$.The reduction in straw yield due to weed infestation is obvious because of the reduced growth and development of vegetative attributes and reduced dry matter production by plants growing under ecologically stress situation of more intense competition with weeds for plant nutrient, moisture and solar radiation resulting in lower photosynthetic efficiency of the crop. Similar result was recorded by Sharma et al., (2017) ${ }^{(10)}$.

Table.1 Effect of different treatments on grain yield (q/ha), straw yield (q/ha) and economics

\begin{tabular}{|l|c|c|c|c|c|}
\hline Treatments & $\begin{array}{l}\text { Grain yield } \\
\text { (q/ha) }\end{array}$ & $\begin{array}{l}\text { Straw yield } \\
(\mathbf{q} / \mathbf{h a})\end{array}$ & $\begin{array}{l}\text { Gross returns } \\
\text { (Rs/ha) }\end{array}$ & $\begin{array}{l}\text { Net returns } \\
\text { (Rs/ha) }\end{array}$ & B: C ratio \\
\hline Nutrient management & \multicolumn{5}{|l}{} \\
\hline N1 & 40.37 & 56.12 & 71,779 & 42,410 & 1.44 \\
\hline N2 & 37.44 & 51.64 & 66,488 & 29,844 & 0.81 \\
\hline N3 & 35.31 & 48.68 & 62,701 & 18,765 & 0.42 \\
\hline LSD(0.05) & $\mathbf{2 . 8 6}$ & $\mathbf{3 . 5 7}$ & $\mathbf{3 4 5 0}$ & $\mathbf{1 8 7 0}$ & $\mathbf{0 . 2 1}$ \\
\hline Weed management & & & & & \\
\hline W1 & 35.57 & 55.60 & 64,422 & 27,049 & 0.72 \\
\hline W2 & 42.50 & 52.25 & 74,221 & 37,237 & 1.00 \\
\hline W3 & 39.43 & 48.51 & 68,858 & 32,441 & 0.89 \\
\hline W4 & 40.23 & 55.63 & 71,492 & 34,533 & 0.93 \\
\hline W5 & 43.83 & 52.37 & 76,216 & 31,892 & 0.72 \\
\hline W6 & 24.67 & 48.50 & 46,728 & 18,889 & 0.68 \\
\hline LSD $(\mathbf{0 . 0 5 )}$ & $\mathbf{2 . 5 7}$ & $\mathbf{3 . 6 1}$ & $\mathbf{3 3 6 2}$ & $\mathbf{1 7 3 9}$ & $\mathbf{0 . 1 7}$ \\
\hline Interaction $(\mathbf{N} \times \mathbf{W})$ & $\mathbf{N S}$ & $\mathbf{N S}$ & $\mathbf{N S}$ & $\mathbf{N S}$ & $\mathbf{N S}$ \\
\hline
\end{tabular}

$\mathrm{N} 1=100 \%$ RDF; N2=75 \% RDF + FYM 5t/ha; N3=50 \% RDF + FYM 10t/ha in main plot, and six weed management practices viz., W1 = Brown manuring; W2= Bispyribac- sodium @ $25 \mathrm{~g} / \mathrm{ha} \mathrm{PoE}$; W3= Chlorimuron ethyl + Metsulfuron methyl (Almix) @ 4 g/ha at 20 DAT; W4=Pyrazosulfuron @ 25 g/ha; W5=Weed free; W6=Weedy check in sub plot 


\section{Economics}

The $\mathrm{B}$ : $\mathrm{C}$ ratio varied significantly among the fertilizer levels. The maximum (1.44) B: C ratio was observed at $\mathrm{N} 1: 100 \% \mathrm{RDF}$ while minimum (0.42) was associated with N2: $50 \%$ $\mathrm{RDF}+\mathrm{FYM} 10$ t/ha. Among the weed control treatments maximum (1.0) B: C ratio was recorded in Bispyribac-sodium which was statistically at par with Pyrazosulfuron and Chlorimuronethyl + Metsulfuron methyl (Almix) and these significantly surpassed over brown manuring and weed free.

The treatment having N1 generated significantly higher grain yield as well as straw yield obviously reflecting in higher B: $\mathrm{C}$ ratio. These findings were conformity with the findings of Saha et al., (2012) ${ }^{(9)}$ and Acharya et al., $(2013)^{(1)}$ expressed the same view. The beneficial effect of chemical weeding on rice yield and in turn on net return had also been observed by Kumari et al., $(2013)^{(7)}$ and Singh et al., $(2014)^{(13)}$. The minimum gross return and net return per rupee of investment was observed in weedy check due the severe crop weed competition resulting in heavy yield reduction. Banerjee and Pal (2012) $)^{(4)}$ and Verma et al., (2014) $)^{(15)}$ were found similar result.

Thus, keeping in view the limitation, that the experiment was conducted for only one year at one location and the validity of the result may lack wide applicability under different environmental conditions tentatively it may be concluded that 100\% RDFand Bispyribacsodium @ 25g/ha PoE would give maximum yield and income to the aromatic rice grower under the semi arid region of Bihar.

\section{References}

1.Acharya SS, Bhattacharya SP. Comparative Efficacy of Pyrazosulfuron Ethyl and Benton with Acetamides for Weed Control in Transplanted BoroRice
(Oryza sativa L.). Int. J. Bio-res. Stress Manag. 2013; 4(4): 506-509.

2. Anonymous. Directorate of rice research, Newsletter. 2017; 15(1).

3. Bali AS, Uppal HS. Effect of date of transplanting and water management practices on yield of basmati rice. Indian Journal of Agronomy. 1995; 40(2):186-192.

4. Banerjee H, Pal S. Response of hybrid rice to nutrient management during wet season. Oryza. 2012; 49(2):108-111.

5. Cochran WC, Cox GM. Experimental designs. Asia Publishing house, Bombay. 1952

6. Fisher RA. Statistical method for research workers $\left(13^{\text {th }}\right.$ Ed.). Olive and Boyd, Edinburgh. 1958

7. Kumari N, Pal SK, Barla S. Effect of organic nutrient management on productivity and economics of scented rice. Oryza. 2013; 50(3):249-252.

8. Puniya R, Pandey PC, Bisht PC. Performance of Trisulfuron, Trisulfuron + Pretilachlor and Bensulfuron- methyl in transplanted rice. Ind. J. Weed Sci. 2007;39(1\&2):120-122.

9. Saha A, Ansari AM, Ahmad E. Effect of herbicides on weeds yield attributes, yield and economics of transplanted rice (Oryza sativa L.). Prog. Agric. 2012; 12(2):337-343.

10. Sharma A, Singh SV, Patel A, Yadav RA. Growth and yield of scented rice (Oryza sativa L.) as influenced by integrated nutrient management practices. Res. Crop. 2017; 18:409-14.

11. Singh B, Malik PK, Yadav A, Nandalal DP. Herbicide efficacy in seeded rice with different method under wet and dry conditions. Ind. J. Weed Sci.2009; 41(1\&2): 37-40.

12. Singh S, Singh H, Narwal S, Malik PK. 2003. Performance of herbicides in transplanted rice. Ind. J. Weed Sci. 2003;35(1 \& 2): 114-116. 
13. Singh S, Singh SP, Neupane MP, Meena RK. Effect of NPK levels, BGA and FYM on growth and yield of rice (Oryza sativa L.). Env. Ecol. 2014; 32(1A): 301-303.

14. Srivastava VK, Bohra JS. Singh JK. Effect of integration of NPK levels and organic sources on growth, yield and economics of rice. Adv. Res. J. Crop Imp. 2013; 4(2): 113-117.

15. Verma, Sandeep, Sultan, Tariq, Ghosh, Gautam. Effect of different levels of fertilizer in combination with biofertilizer on yield of transplanted rice. Environ. Ecol. 2014; 26(3): 181-188.

\section{How to cite this article:}

Shashimala Kumari, Vinay Kumar, Shashidhar Yadav, Vijay Kumar, Santosh Kumar Singh, Rajan Kumar and Ravi Nandan. 2020. Effect of Nutrient and Weed Management Practices on Yields and Economics of Aromatic Rice in Semi Arid Region of Bihar, India. Int.J.Curr.Microbiol.App.Sci. 9(03): 89-95. doi: https://doi.org/10.20546/ijcmas.2020.903.011 